\title{
Ship Recycling Financial Instruments: A Tax or Not a Tax?
}

\author{
Some Brief Reflections
}

Han Kogels \& Ton Stevens*

\begin{abstract}
In this article the question is reviewed whether two by the EU Commission proposed financial instruments to stimulate 'green' ship scrapping, (i) a Ship Recycling Fund (SRF) and (ii) a Ship Recycling License (SRL), might be qualified as a 'tax' under Article 192(2) TFEU. Qualification as such a "tax" would mean that the EU Commission can only introduce such a financial instrument with unanimity voting. The authors first explore the concept of 'tax' in the TFEU in general and in Article 192(2) TFEU in particular. Based on this analysis, the authors conclude that levies paid to an SRF might be qualified as an 'earmarked tax' falling within the definition of a 'fiscal provision' in the meaning of Article 192(2) TFEU, which means that levies to such a fund can only be introduced by unanimity voting. The SRL fee consists of two elements: (i) a fee to cover administrative expenses and (ii) a contribution to a savings account. The fee to cover administrative expenses is qualified by the authors as a retribution that should not be qualified as a fiscal provision in the meaning of Article 192(2) TFEU. The contribution to a blocked savings account can neither be qualified as a tax nor as a retribution. Therefore, the SRL fee can be introduced without unanimity voting by the EU Council.
\end{abstract}

Keywords: Ship Recycling Fund, Ship Recycling License, green ship scrapping, EU concept of tax, earmarked tax

\section{Introduction}

In June 2016, the Final Report 'Financial instrument to facilitate safe and sound ship recycling' (hereafter 'the Report') was issued to the European Commission by a team of Ecorys, DNV-GL and Erasmus School of Law. ${ }^{1}$ In that Report the research team proposed the socalled Ship Recycling License (hereinafter 'SRL') as a solution for a financial incentive that would facilitate

* H.A. Kogels is Emeritus professor of European tax law Erasmus School of Law. A.J.A. Stevens is Professor of corporation tax law Tilburg University and of counsel Loyens \& Loeff, Rotterdam. He was previously holding the chair of international tax law at Erasmus School of Law and initially involved in the ship recycling financial instrument project but did not participate in the drafting of the final report.

1. https://ec.europa.eu/environment/waste/ships/pdf/

financial_instrument_ship_recycling.pdf. safe and sound ship recycling. This solution was positively welcomed by the EU Commission in its reaction of August $2017^{2}$ (hereafter 'the Commission Reaction'). One of the main features of the SRL proposal ${ }^{3}$ is the requirement of a license to visit European ports against payment of a license fee. This license fee consists of two elements: (i) a minor administrative cost charge and (ii) a premium earmarked to each individual ship. In the view of the Report, ${ }^{4}$ the SRL license fee is not a tax, which means that the EU Commission can introduce the SRL without unanimous consent of all the EU Member States (and through a separate EU agency instead of the tax authorities of Member States). However, in the literature on this subject, there is at least one dissenting view. ${ }^{5}$ It should be noted that the concept of tax within EU law is a rather unexplored area with little guidance of EU court decisions and literature. ${ }^{6}$ Therefore, in this contribution the authors will try to answer the following research question: Is the SRL license fee a (EU) tax or not?

To answer this research question, we will first analyse (Section 2) the concept of tax in general and in a EU law context. In Section 3 the relationship between the EU law concept of tax and the competence of the EU bodies with regard to taxation is further explored. The findings of Sections 2 and 3 are used to analyse in Section 4 two ship recycling financial instruments: the Ship Recycling Fund (hereinafter SRF, as proposed in a previous stage $)^{7}$ and the SRL as proposed in the Report. We conclude our article (Section 5) with a summary of our findings.

2. Report from the Commission to the European Parliament and the Council on the feasibility of a financial instrument that would facilitate safe and sound ship recycling, COM (2017), 420, Brussels, 8 August 2017.

3. The key principles of the SRL are summarised in para. 3 of the Commission Reaction: see below in para. 4.3.

4. See para. 2.3 of the Report, at 35 .

5. H. Jessen, 'Safe and Environmentally Sound Ship Recycling: Obligations and Liabilities Under EU Law and Public International Law', in Piraeus Bar Association, 9th International Conference of Maritime Law (2016), Maritime Safety \& Security, Congress Reports, at 150-153.

6. B. Peeters (ed.), The Concept of Tax, EATLP International Tax Series, Vol. 3 (2005) (hereinafter 'EATLP Report') notably Part 2 'The concept of tax in EU law'.

7. Under the SRF-alternative ships calling at EU ports have to pay a ship recycling levy to a separate EU fund. At scrapping a ship the ship owner may receive a payment out of the fund to bridge the financial gap between 'green' and 'not-green' scrapping. See in more detail para. 4.2 hereafter, as well as the Report, at 30/31. 


\section{The Concept of Tax}

\subsection{General}

From the EATLP Report it can be derived that the definition of taxes differs in each state. Furthermore, the overall conclusion ${ }^{8}$ regarding the definition of taxes seems to be threefold: such definition (i) is not static, (ii) heavily depending on the goal and its legal setting and (iii) suffering from a vague border between taxes and retributions (or charges).

Nevertheless, in many countries there is a rough division between 'taxes' on the one hand and 'fees' (retributions, duties) on the other.

Taxes $^{9}$ can be characterised as forced payments to the government, while the government does not offer any direct, individual performance in return. Revenues go to the general means of the government and can be spent by the government as it sees fit.

Fees (retributions, duties) can be distinguished from taxes because they are levied for a specific, individual service rendered by the government, acting in its governmental capacity. There are no fees due when the government has not rendered any services. Furthermore, it is quite often required that the fee is established in such a way that the projected revenue does not exceed the projected costs of the service.

In some countries, such as the Netherlands, ${ }^{10}$ next to general taxes so-called earmarked taxes are qualified as a separate species of 'taxes'. An earmarked tax can be distinguished from a general tax because the former entails a form of cost recovery. The costs of certain public/municipal facilities are allocated towards a group of benefiting taxable persons. Regarding earmarked taxes, the service provided by the government does not, unlike fees, have to render any individual profit, but it does have to render a profit for the specific group as a whole. As a typical example of such an earmarked tax ('bestemmingsbelasting') within the Dutch context sewage charges can be mentioned: sewage charges are levied by the Dutch municipalities from their citizens but must be linked to the maintenance of the municipal sewage infrastructure. tudering van het begrip 'belastingen, Geschriften van de VBW, nr. 184, at 10, K. Tipke and J. Lang, Steuerrecht, 18th ed. (2005), at 47-49, and M. Helminen, 'The Notion of Tax: General Report', in Cahiers de droit fiscal international of the International Fiscal Association IFA, Vol. 101 B (2016), Sdu The Hague.

10. H.J. Hofstra and C. van Raad, Inleiding tot het Nederlands belastingrecht, 7th ed. (1992), at 22

11. In Art. 2 of the OECD Model Convention on Income and Capital 2008 only the taxes on income and capital covered by that Model Conventions are described. The same goes for Art. 2 of de UN Model Double Taxation Convention between Developed and Developing Countries 2017. As neither the SRF nor the SRL relates to any levy on income or capital, we will not go further into the OECD and UN definitions of tax.

\section{$2.2 \mathrm{EU}$}

There is no definition of taxes in the TFEU. ${ }^{11}$ Nevertheless, the term 'taxes' is mentioned in several articles of the TFEU:

- Article 30 TFEU (customs duties): "customs duties on imports and exports and charges having equivalent effect....(and) ....customs duties of a fiscal nature" are prohibited between Member States; ${ }^{12}$

- Article 110 TFEU (internal taxation): "internal taxation of any kind";

- Article 113 TFEU (indirect taxes): "turnover taxes, excise duties and other forms of indirect taxation";

- Article 114(2) TFEU (direct taxes): "fiscal provisions";

- Article 192(2) TFEU (protection of the environment): "provisions primarily of a fiscal nature".

The general view in the literature ${ }^{13}$ seems to be that the EU concept of taxes is independent from the concept of taxes in the legal systems of the EU Member States and is of a functional nature: its function clearly is to determine the distribution of taxing powers between the Member States and the European institutions. The concept of tax is not intended to influence domestic legislation, but rather to determine when the EU institutions should apply the unanimity rule for approval of certain EU Directives. ${ }^{14}$ This competency question is discussed in the following chapter.

\section{Competence of the EU Regarding Taxation}

The financial instruments (the SRF and the SRL) discussed in this article might be qualified either as an indirect tax or an environmental tax. From a competency view there is no difference in the qualification of the financial instrument as either an indirect tax or an environmental tax. In both cases (Art. 113 respectively Art. 192(2) TFEU) measures can only be introduced by unanimity within the EU Council. However, there are some important differences in the competency articles referring to indirect taxes and environmental taxes. According to Article 113 TFEU, the Council shall adopt provisions for the harmonisation of (national) legislation concerning turnover taxes, excise duties and other forms of indirect taxation. The object of Articles 191 and 192 TFEU, however, is a different one, notably to implement the EU environmental policy, based on the polluter-pays principle, by means of environmental taxes and by other economic and/or financial instruments. The general view ${ }^{15}$ seems to be that under Article 192 TFEU

12. Neither the SRF nor the SRL falls under the concept of customs duties. According to Art. 31 TFEU, Common Customs Tariff duties shall be fixed by the Council and therefore are the competence of the Council.

13. P. Herrera, EATLP-Report, at 207-208.

14. Ibid., at 209

15. See W. de Wit, Nationale milieubelastingen en het EG-verdrag, Kluwer (Deventer, 1997), para. 4.6.2. 
both harmonisation and introduction of new measures is possible, however, with regard to taxes ('provisions primarily of a fiscal nature') only with unanimity voting. Also an EU environmental tax or levy is possible, however, only in case the funds received are not used for the EU budget but for the funding of specially labelled (e.g. in a separate fund) environmental measures.

In the literature ${ }^{16}$ there is a broad definition of 'taxes' regarding both indirect and environmental taxes. This would mean that the term 'taxes' or 'provisions primarily of a fiscal nature' would include next to general taxes also earmarked taxes and even retributions (other fees and charges). However, in the German literature, ${ }^{17}$ the term 'fiscal provisions' in Article 192(2) TFEU refers to 'taxes' only and not to retributions (other fees and charges). This seems also the view of the EU Council and EU Commission, because a number of EU Directives $^{18}$ have not been adopted by the unanimity rule, even if they oblige EU Member States to increase their charges on water supply ${ }^{19}$ or on the use of roads by heavy vehicles. ${ }^{20}$ This view of the German literature, however, is not generally accepted ${ }^{21}$ and the trend to 'repackage' a tax as other economic measure to avoid unanimity voting might be criticised. On the other hand, Articles 191 and 192 TFEU provide the EU Council to introduce new measures to achieve EU environmental policy both by means of taxes (fiscal provisions) and by other financial instruments. The only difference between these two forms is the unanimity or majority voting. The EU Commission and EU Council seem free to go either way, unless the economic instrument actually serves as a 'tax'. In our view, therefore, the term 'fiscal provision' includes both general taxes and earmarked taxes, but does not include retributions (other fees and charges) unless such retributions actually function as a tax.

\section{Analysis of Ship Recycling Financial Instruments}

\subsection{General}

From the above it can be revealed that there is no definition of 'taxes' contained in the TFEU. The term 'taxes' in various articles of the TFEU is of a functional nature, i.e. its first object is to divide competencies within the EU. If the ship recycling financial instruments can be qualified either as indirect taxes or as envi-

16. P. Selicato, EATLP-Report, at 232-234, and de Wit, above n. 15, para. 2.1.

17. See the reference made by Herrera, above n. 13, at 216 (footnote 1).

18. See Herrera, above n. 13 , at 216 , and Selicato, above n. 16, at 251-253.

19. Directive 2000/60/EC of 23 October 2000, establishing a framework for Community action in the field of water policy.

20. Proposal for a Directive amending Directive 1999/62/EC on the charging of heavy goods vehicles for the use of certain infrastructures. See also the discussion on payments related to emission permits for greenhouse gas emission allowance trading in Selicato, above n. 16, at 252.

21. See Herrera, above n. 13, at 216 and 254 ronmental taxes, in both cases 'taxes' can only be harmonised or introduced by unanimity vote. From the function of the term, the general view in the literature seems to be that the term 'taxes' should be explained in a broad manner. However, with respect to environmental taxes, the prevailing view of both literature and the EU Commission/EU Council seems to be that retributions (other fees and charges) are excluded from the term 'taxes' (provisions of a fiscal nature). Hereafter, both the SRF and the SRL are analysed separately. According to Article 401 of the VAT Directive, without prejudice to other provisions of Community law, Member States can maintain or introduce any taxes, duties or charges which cannot be characterised as turnover taxes. ${ }^{22}$ From the preamble of this Directive it is clear that the value added tax system (VAT) is the only system Member States can apply to levy a turnover tax on goods and services, because it safeguards that within the territory of each Member State the final consumer bears the same burden on similar goods and services, regardless of the length of the production and distribution chain.

In case law of the EU Court of Justice, the interpretation of the European concept of turnover tax (VAT) is based on four essential characteristics: (1) general application to all transactions made regarding goods and services, (2) proportionality to the price charged in return for the goods and services supplied, (3) charged at each stage in the production and distribution chain and (4) application exactly on the added value of goods and services. ${ }^{23}$ Neither the SRF nor the SRL has the essential characteristics of the EU concept of a turnover tax. For that reason, we limit our analysis below to the question whether the SRF or the SRL can be qualified as an environmental tax.

\subsection{Ship Recycling Fund (SRF)}

In a previous stage, a financial instrument introducing an SRF was proposed. From the Report, ${ }^{24}$ we derive the following main features of such instrument:

- All (EU-flagged) ships calling at EU ports have to pay a ship recycling levy (which will be levied as an additional port fee by the EU Member States);

- The EU Member States are obliged to pay-on the collected ship recycling levies into a separate fund (EU level recycling fund) to support safe and environmentally sound ship recycling of EU-flagged ships;

- If an EU-flagged ship is scrapped on a qualifying ship dismantling facility, the (ultimate) ship owner receives a payment (premium) out of the fund to bridge the financial gap between 'green' and 'notgreen' scrapping.

22. Council Directive 2006/112/EC of 28 November 2006 on the common system of value added tax (https://eur-lex.europa.eu/legal-content/ EN/TXT/PDF/?uri=CELEX:32006L0112\&from=EN).

23. See Selicato, above n. 16, at 235-239.

24. See the Report, above n. 7, at 30. 
In our view, the ship recycling levies might be qualified as compulsory, non-requited payments into a separate fund (the EU level recycling fund) with a specific goal (the support of safe and environmentally sound ship recycling). The premium is only received by the (ultimate) ship owner who scraps on qualifying 'green' ship dismantling facilities. There seems to be no clear relation between the levy and the premium received on an individual basis. For that reason, such levies might be qualified as an earmarked tax. From the above, it can be concluded that a levy as suggested in the SRF would be an earmarked tax that should be qualified as a 'fiscal provision' in the meaning of Article 192(2) TFEU, which means that such levies can only be introduced by unanimity voting.

\subsection{Ship Recycling License}

In the Final Report (2016), instead of the SRF and some other alternatives, the SRL is proposed as the preferred financial instrument to stimulate safe and environmentally sound ship recycling. This solution was positively welcomed by the EU Commission in its reaction of August 2017. From the Report, ${ }^{25}$ the following main features of the SRL can be derived:

- When a ship visits a European port, a license (SRL) is required;

- Such license can be acquired through a new or existing EU agency;

- The license can only be acquired against a fee. The fee consists of two elements: (i) a small fee $(0.8 \%)$ to cover administrative expenses and (ii) a contribution $(99.2 \%)$ to a (blocked) savings account which is earmarked to the individual ship;

- The contribution (premium) levied will depend on the capital amount that needs to be accumulated to bridge the financial gap between dismantling in a substandard yard and dismantling in a yard included on the European ('green') List at the end of the ship's lifetime;

- The full capital amount accrued on the savings account is tied to the ship and will be paid to the ultimate owner of the ship on the condition that the ship was sent to a qualifying ship recycling facility (a ship recycling facility which is accredited and mentioned on an European List);

- If the ship will ultimately not be sent to a qualifying ship recycling facility, the capital amount will be forfeited and falls into a special fund (which is used to subsidize the capital amounts of other vessels with license or to stimulate 'green' ship recycling in other ways).

Could the SRL fee be qualified as a 'fiscal provision' in the meaning of Article 192(2) TFEU? From the case law of the ECJ in relation to the term 'taxes' in both Article 113 and 192(2) TFEU it can be derived that the fee should be analysed per separate element. In the case of the SRL two elements can be distinguished: the administrative fee and the contribution (premium). Assuming that the administrative fee only recovers administrative costs, it is not a tax but a retribution. Such retribution can, in our view, not be (re)qualified as a 'fiscal provision' in the meaning of Article 192(2) TFEU. Therefore, there is no need for applying the unanimity voting provision.

Also the premium cannot be qualified as a 'provision primarily of a fiscal nature' (a tax) in the meaning of Article 192(2) TFEU. In our view, it is not even a retribution because the ship owner maintains the right on the (accrued) capital amounts and receives back the (accrued) capital amount at the time point the ship is scrapped on a qualifying ship recycling facility. In fact, the premium system works as an obliged savings account (compared to an obliged pension plan).

The penalty for not opting for recycling in a qualifying facility (i.e. the forfeiture of the accrued rights) will in our view not change the instrument into a 'provision primarily of a fiscal nature', assuming that the main objective of this measure is to oblige ship owners to finance themselves to bridge the financial gap between 'green' scrapping and 'non-green' scrapping. If the ship owner chooses for 'non-green' scrapping, he will lose his accrued premiums (capital) 'saved' in the fund, which can be considered a penalty for 'non-green' scrapping. The final conclusion, therefore, is that also the premium element is not a 'fiscal provision' in the meaning of the TFEU and the SRL instrument can, in our view, be introduced without unanimity voting.

\section{Summary/Conclusions}

In this article the question is reviewed whether the proposed financial instruments, an SRF or an SRL, might be qualified as a 'tax' under Article 192(2) TFEU. Such qualification as a "tax" would mean that the EU Commission can only introduce such a financial instrument with unanimity voting. Although there is no definition of taxes in the TFEU, the prevailing view seems to be that the term 'fiscal provision' (tax) in Article 192(2) TFEU includes both general taxes and earmarked taxes, but should not include retributions (fees and other charges). Based on this view, both financial instruments have been analysed. The SRF can be qualified as an earmarked tax and for that reason might be only introduced with unanimity voting. The SRL fee consists of two elements: (i) a fee to cover administrative expenses and (ii) a contribution to a savings account. The fee to cover administrative expenses is clearly a retribution that should not be qualified as a fiscal provision in the meaning of Article 192(2) TFEU. The contribution to a blocked savings account can neither be qualified as a tax nor as a retribution. Therefore, such instrument can be introduced without unanimity voting by the EU Council. 